IZA DP No. 8128

Health, Height and the Household at the Turn of the 20th Century

Roy E. Bailey

Timothy J. Hatton

Kris Inwood

April 2014 


\title{
Health, Height and the Household at the Turn of the 20th Century
}

\author{
Roy E. Bailey \\ University of Essex \\ Timothy J. Hatton \\ University of Essex, \\ Australian National University and IZA \\ Kris Inwood \\ University of Guelph
}

\section{Discussion Paper No. 8128 \\ April 2014}

IZA

P.O. Box 7240

53072 Bonn

Germany

Phone: +49-228-3894-0

Fax: +49-228-3894-180

E-mail: iza@iza.org

Any opinions expressed here are those of the author(s) and not those of IZA. Research published in this series may include views on policy, but the institute itself takes no institutional policy positions. The IZA research network is committed to the IZA Guiding Principles of Research Integrity.

The Institute for the Study of Labor (IZA) in Bonn is a local and virtual international research center and a place of communication between science, politics and business. IZA is an independent nonprofit organization supported by Deutsche Post Foundation. The center is associated with the University of Bonn and offers a stimulating research environment through its international network, workshops and conferences, data service, project support, research visits and doctoral program. IZA engages in (i) original and internationally competitive research in all fields of labor economics, (ii) development of policy concepts, and (iii) dissemination of research results and concepts to the interested public.

IZA Discussion Papers often represent preliminary work and are circulated to encourage discussion. Citation of such a paper should account for its provisional character. A revised version may be available directly from the author. 
IZA Discussion Paper No. 8128

April 2014

\section{ABSTRACT}

\section{Health, Height and the Household at the Turn of the 20th Century}

We examine the health and height of men born in England and Wales in the 1890s who enlisted in the army at the time of the First World War. We take a sample of the army service records and use this information to find the recruits as children in the 1901 census. Econometric results indicate that adult height was negatively related to the number of children in the household as well as to the share of earners, the degree of crowding, and positively to socioeconomic class. Adding the characteristics of the local registration district has little effect on the household-level effects. But local conditions were important; in particular the industrial character of the district, local housing conditions and the female illiteracy rate. We interpret these as representing the negative effect on height of the local disease environment. The results suggest that changing conditions at both household and locality levels contributed to the increase in height and health in the following decades.

JEL Classification: I12, J13, N33

Keywords: $\quad$ heights of recruits, household structure, health in Britain

Corresponding author:

Tim Hatton

Department of Economics

University of Essex

Colchester CO4 3SQ

United Kingdom

E-mail: hatton@essex.ac.uk 


\section{Introduction $^{1}$}

An extensive literature has examined the heights of children and adults during the nineteenth century and earlier to provide a window on the proximate determinants of health. As is widely recognized, height is influenced both by nutrition and by the surrounding disease environment during infancy and childhood. Most studies of the heights of adults analyse military recruits or conscripts but the information on childhood circumstances is often limited to characteristics of the locality in which they were born and perhaps the occupation of the individual or that of his father. Yet the inferences drawn from these studies often relate to the conditions within the household, for which local area characteristics can be only a rough proxy. As a result it has not generally been possible to distinguish between those effects that genuinely stem from within the household and those that arise from the locality, such as the local disease environment. As we shall see this distinction may be important for understanding the socioeconomic determinants of health and height and these can contribute to explaining both cross-sectional variations and longrun trends.

In this paper we analyse for the first time a sample of soldiers who enlisted in the British army around the time of the First World War. Given the vast numbers that were recruited, these are likely to be a more representative cross section of British males than samples observed in peacetime. And all the more so as we focus exclusively on those born in the 1890s, who were young adults during the War and for whom enlistment rates were extremely high. In order to capture the conditions in which they grew up we identify the households of the servicemen in the 1901 census. Because we search each case individually using the information recorded upon enlistment we achieve a remarkably high match rate of 85 percent. We also link the individuals and their childhood households to the characteristics of the registration districts in which they were located. This gives a much finer classification of local conditions that would be possible at the county level, while ensuring a mix of urban and rural locations.

Our findings point to a number of household features that are associated with differences in adult height. These affect height through both nutrition and disease. The first is the negative effect on height of the number of brothers and sisters. Our results therefore support the idea of a trade-off between the quantity of children and their quality in terms of health-

\footnotetext{
${ }^{1}$ Acknowledgements: We thank the ANU College of Economics and Business for a Research School Grant and the Social Sciences and Humanities Research Council of Canada for financial support under Grant No. 41020092342. We are grateful to Danielle van Wagner, Jeremy van Dyke and Mitsumasa Aoki for excellent research assistance, and to seminar participants at Essex, Hamburg, the London School of Economics and the Economic History Society conference at Warwick for useful comments.
} 
something that is widely believed for the nineteenth century, but rarely measured. Other results include a negative effect of overcrowding on height as well as a negative effect of the share of earners in the household. In the presence of these variables the occupational class of the head of household also has a significant effect. However, local conditions still matter, in particular the disease environment as represented by infant mortality. This finding is consistent with those of other studies, and underlying it is the degree of overcrowding in the locality, its industrial character and the extent of female illiteracy. The last of these supports the idea that a more educated female population was conducive to the better nurturing of children.

\section{Childhood determinants of height}

Height is now a widely accepted indicator of the health status of populations. Aside from genetic influences, height is determined during childhood by nutrition and by the disease environment. A large literature has explored the socioeconomic circumstances that influence the average heights of populations in the eighteenth and nineteenth centuries and how these factors have evolved over time. ${ }^{2}$ Important influences on height have been identified in a wide variety of cross sectional studies as well as in those that examine changes over time. Cross sectional studies of individual heights potentially offer more nuanced insights than can be obtained from variations in average height across regions or over time. But studies of individual heights, such as army recruits or convicts, often suffer severe limitations because they lack detailed information on socioeconomic conditions during childhood. ${ }^{3}$ Thus inferences have to be based on not much more than place of birth characteristics and occupation or father's occupation. As a result there is little direct evidence on the correlates of height at the household level.

Modern datasets have provided a wealth of information on height and other health indicators for a wide range of developed and developing countries and the results have sometimes been used to make inferences about historical populations. But the past may differ in important respects. ${ }^{4}$ One issue in the literature is the distinction between the influence of household circumstances and the effect of conditions in the locality, a distinction that is sometimes referred to as 'composition versus context'. When only the locality variables are available it is unclear whether these represent genuine locality effects or simply an average of household effects. Thus "neighbourhood level variables may act partially or entirely as proxies for individual attributes and a partition of the contribution of

\footnotetext{
${ }^{2}$ Comprehensive surveys are provided by Steckel, 'Stature and the standard of living' and 'Heights and human welfare'.

${ }^{3}$ Notable studies among a long list include Humphries and Leunig, "Cities, market integration', Horrell and Oxley, 'Bringing home the bacon', A'Hearn, 'Anthropometric evidence', Baten and Murray, Heights of men and women', Baten, 'Protein Supply and Nutritional Status'. A few studies such as Lantzsche and Schuster, 'Socioeconomic status' include a wider array socioeconomic variables, but these are observed at the time of enlistment rather than during childhood. Haines et al., 'The short and the dead', match records for Union Army soldiers with household data on wealth and head's occupation, but with a match rate of less than one third.

${ }^{4}$ See Konteh, 'Urban sanitation.'
} 
each to the chosen health outcome is impossible. Without neighbourhood level measures, the impact of individual characteristics may be misunderstood." ${ }^{5}$ The weight of evidence in modern studies is that the locality plays only a minor role, but the results could be quite different for the nineteenth century. ${ }^{6}$ Distinct locality effects would include not only the built environment, the sanitary infrastructure and industrial pollution but potentially also human and social capital. ${ }^{7}$

At the household level a number of conditions are important for child health and growth. Perhaps most important is the socio-economic status of the household. This is typically represented by the occupational class of the head of household-often the fathers of the individuals whose heights are analysed. Not surprisingly, differences in height by social class, and changes in those differentials, have been widely analysed. ${ }^{8}$ But their interpretation is less than transparent, not least because of clustering by locality. Taken alone, occupational class stands for a variety of factors, the most obvious of which is income, but it may also capture the separate effects of education, skills, standards, norms or other aspects of social standing that independently affect the health of children. On the other hand, even if social or occupational class were a good proxy for income, its effects may work through housing quality and overcrowding as well as diet and nutrition. In Victorian households the head's income could be supplemented by that of other earners and so the number and composition of earners might also be important. But even this might have mixed effects, depending on how time and resources were distributed among different family members by age, sex and labour market status. ${ }^{9}$

Household demographics are likely to matter but their effects are difficult to observe. The most obvious factor is the number of children in the family. As Rowntree found in his 1899 survey of York, large families were a common 'cause' of poverty. ${ }^{10}$ Biographical evidence provides graphic detail that large families were often associated with disadvantage and privation among children. ${ }^{11}$ Although the idea of a trade-off between the number of children in a family and their average health is familiar, quantitative evidence for the

\footnotetext{
${ }^{5}$ Pickett and Pearl, 'Multilevel analyses' p. 116.

${ }^{6}$ Pickett and Pearl, 'Multilevel analyses' p 111; Stafford and Marmot, Neighbourhood deprivation,' p. 357; Martikainen et al., 'Effects of the characteristics of neighbourhoods', p. 213; Komlos and Lauderdale, 'Spatial correlates of US heights', p. 71.

${ }^{7}$ Newell and Gazeley, 'The declines in infant mortality' provide evidence that sanitary reforms reduced infant mortality in English towns at the turn of the century. In a controversial article Szreter and Woolcock, 'Health by association?', draw links between the development of social capital, specifically 'bridging' and 'linking' capital, and the advancement of sanitary infrastructure in nineteenth century Britain. In the absence of a welldeveloped public health service, 'bonding' social capital could also be important. For a recent survey of empirical work on social capital and health-related outcomes of children, see Vynke et al., 'Does neighbourhood social capital aid'.

${ }^{8}$ Lantzsch and Schuster, 'Socioeconomic status and physical stature' include occupation of both conscripts and their fathers. Among the many studies that examine the effects of socioeconomic status are Cavelaars et al. 'Persistent variations' and Breschi et al., 'Social status'.

${ }^{9}$ Horrell and Oxley, 'Crust or crumb?'

${ }^{10}$ Rowntree, Poverty, pp. 120-1, 134-7.

${ }^{11}$ Humphries, 'Because there are to menny'.
} 
nineteenth century is thin. Some studies have identified a negative relationship between fertility and height in aggregate time series, but there is little evidence at the household level. ${ }^{12}$ One exception is evidence from the Boyd Orr cohort of children in poor families in the 1930s, which strongly supports the view that larger families were associated with shorter stature. ${ }^{13}$ But evidence for earlier periods is lacking.

An issue that concerned contemporary observers was whether mothers' working in the labour market was deleterious to the health and survival of their children. On one hand working mothers may have less time for nurturing children, but on the other hand they may have fewer children and more income. Such hypotheses can only be examined with data at the household level. The demographic structure of the household may influence child health not only through the availability of nutrition but also via the transmission of disease. The latter is often linked with overcrowding, or more precisely to the interaction between housing quality and household demography. This was a perennial concern of medical professionals of the late nineteenth century, who drew strong links between overcrowding and the spread of infections, especially as a cause infant and child mortality. ${ }^{14}$ A number of studies have found strong associations between health outcomes and overcrowding, or housing conditions more generally, but almost always at the aggregate level. ${ }^{15}$ As a result it is unclear how far housing conditions affect the individual household directly and how far they stand as a proxy for conditions in the locality at large.

Turning to the local environment, attention has frequently been drawn to the differences height, and even greater differences in mortality, between rural and urban locations. ${ }^{16}$ The height advantage of those from rural locations is typically associated with better access to fresh food (or at least to lower prices) and to lower exposure to infections endemic to towns and cities. Such differences are often seen as locality effects but taken alone they would also capture compositional effects such as differences in income, housing and family structure. The evidence suggests that proximity to sources of basic foods such as grain, vegetables, milk and butter, and meat products, identified by locality, had significant effects

\footnotetext{
${ }^{12}$ See Weir, 'Parental consumption decisions'; Schneider, 'A historical note on height'.

${ }^{13}$ Hatton and Martin, 'The effects on stature'.

${ }^{14}$ Notable among these was Sir Arthur Newsholme who was Medical Officer of the Local Government Board 1909-1919 and Sir George Newman Chief Medical Officer to the Board of Education from 1907, and then from 1919 Chief Medical Officer to the newly created Ministry of Health. Newsholme, Infant and child mortality, saw poverty as well as housing conditions as key causes of high infant mortality but laid stress on the environment external to the household, including public sanitation, temperature and rainfall. By contrast Newman, Infant mortality, laid stress on the education and practices of mothers. Interestingly, neither accepted the view that high fertility contributed to infant mortality. See the admirable summary of their respective views in Woods, The demography of Victorian England and Wales, pp. 280-295.

${ }^{15}$ See for example, Burstrom et al, 'Child mortality in Sweden'; Cage and Foster, 'Overcrowding and infant mortality'.

${ }^{16}$ On the interpretation of urban-rural mortality gaps, see Williams and Galley, Urban-rural differentials'; Szreter and Mooney, 'Urbanisation, mortality and the standard of living'; Woods, The demography of Victorian England and Wales, Ch. 9.
} 
on height. ${ }^{17}$ These attributes varied across rural locations and also between towns and cities with differential access to transport networks and to rural hinterlands.

Perhaps even more important is the link between population density and height. A number of studies have found that larger and more industrial cities were associated with shorter stature. Clearly, high density is associated with poor housing quality and overcrowding and it may simply reflect the circumstances of individual households. But one recent study points to effects stemming from the surrounding area and not just the immediate vicinity, which suggests that conditions in the surrounding locality were important. ${ }^{18}$ Indeed the widespread presumption is that high population density captures the local disease environment. Nineteenth century cities are famous for grime and squalor lack of sanitation, not to mention industrial pollution. But the gradual, if uneven, advance of sanitary reforms, improved public amenities, cleaner streets and suburbanisation helped to remove some of the disease vectors. As a result the effects captured by population density may have become weaker and more heterogeneous towards the end of the nineteenth century.

One way to capture the local health environment is to look at average health outcomes. The most widely used measure is the infant (or sometimes child) mortality rate. This could have two opposite effects. On one hand higher infant mortality might leave healthier and taller survivors - the selection effect. On the other hand as a proxy for the risk of infection it may result in shorter stature-the scarring effect. Existing evidence for countries and localities points to a strong negative relationship between infant mortality around the time of early childhood and height, which suggests that the scarring effect dominates. ${ }^{19}$ In the nineteenth century spatial and temporal variations in infant mortality were associated largely with respiratory infections, notably pneumonia and bronchitis, and gastro-intestinal infections, especially diarrhoea and dysentery. These types of infection, especially when recurrent, were precisely those that slowed growth during childhood. But other infectious diseases (measles, whooping cough, scarlet fever) may not be so well captured. ${ }^{20}$ It is important to note, however, that while infant mortality stands as a proxy for some elements of the disease environment, it represents an outcome of a variety of deeper causes, some of which are noted above.

To summarise, the existing literature points to a variety of economic and demographic circumstances that affect both nutrition and infection and that promote or restrict growth during childhood. But many of the inferences, particularly for the nineteenth century and earlier, are indirect in the sense that they are derived from the relationship between individual heights and the characteristics of regions or localities. The most important limitation has been the lack of information on household circumstances during childhood. A

\footnotetext{
${ }^{17}$ See Baten and Murray, 'Heights of Men and Women'; Baten, 'Protein Supply and Nutritional Status'.

${ }^{18}$ Humphries and Leunig, 'Cities, market integration'; see also Komlos and Lauderdale, 'Spatial correlates of US heights'.

${ }^{19}$ Hatton, 'Infant mortality', Bozzoli et al. 'Adult height and childhood disease'.

${ }^{20}$ Woods, The demography of Victorian England and Wales, pp. 272-3.
} 
related issue is the degree to which locality effects influence health during childhood once household circumstances are taken into account. In what follows we investigate both household and locality effects using a sample of British servicemen in the First World War.

\section{Data}

We construct a database of the heights of men who served in the British army around the time of the First World War. These come from the army service records, which have now been made available online largely for the benefit of genealogists. ${ }^{21}$ The original records are kept in the National Archives and a number of features are worth noting. Our focus is on the army service records that are located in the file WO 363, also known as the "burnt documents'. As a result of fire at the War Office building at Arnside Street in London in September 1940, approximately three fifths of the records were destroyed by fire and many others were damaged. ${ }^{22}$ The surviving documents contain records of around two million servicemen who completed their army service between 1914 and the early 1920s. They exclude recruits to the navy and those who entered the army as officers. Although the files for individual servicemen are sometimes incomplete, almost all of them include the attestation form that was completed upon enlistment. Most of the information that we use here comes from the attestation. Although there are different types of attestation form, almost all include the date and place of attestation, the name, age, sometimes the birthplace, and usually the address of the serviceman and/or his next of kin. From the medical inspection report we also have some physical characteristics, most importantly height.

We have sampled these records using the genealogical website Ancestry.co.uk. We sample the service records on the basis of the first three letters of the surname. We have taken a sample of the first 2.5 percent of each three-letter combination for about half of the letter combinations. Our principal focus is on those that were born in the years 1892 to 1897 in order to observe them as children in the 1901 census. The ages that were recorded on the attestation, and those that we have calculated independently, were sometimes inconsistent with the summary upon which the search was based. As a result we have a rather wider range of ages than in the original sampling frame.

Based on information in the service record we searched for each of the servicemen in the 1901 census, this time using the genealogical website Findmypast.co.uk. ${ }^{23}$ Initially we search by age range and name, and then, where available, we use other information in the service record for further corroboration or to discriminate between alternative possibilities. The most important pieces of corroborative information are birthplaces and the names and

\footnotetext{
${ }^{21}$ For a guide to these records (for genealogists) see Spencer, 'First World War Army Service Records.'

${ }^{22}$ For this reason it is not possible to determine whether a particular person served in the army or not. It is impossible to distinguish whether a person did not serve in the army or whether their record was destroyed.

${ }^{23}$ We use Findmypast rather than Ancestry because the search engine is rather more discriminating and also because the household summary is presented in a way that lends itself more easily to data entry.
} 
addresses of next of kin. One helpful feature is that few of the servicemen that we search for were married at the time of enlistment and so their next of kin is typically a parent rather than a spouse. This aids in identifying the correct household in 1901. In addition to recording the key information from the 1901 census we also assess the quality of the match with grades ranging from 4 (certain) to 1 (most likely). ${ }^{24}$ Cases where no match was found or there was no basis to choose among alternatives were dropped. Among the cases that were successfully matched the match grades are $4: 54.0 \%, 3: 26.0 \%, 2: 13.1 \%, 1: 6.9 \%$. Our matched sample (grades 1-4) amounts to 2522 servicemen who grew up in England Wales out of a total of 2956 for whom we have searched in the census. Because we have investigated each case individually our match rate of 85.3 percent far exceeds those typical of studies that rely only on electronic matching. This should provide a reasonable degree of confidence that our sample is representative of all servicemen.

We focus on those from England and Wales for two reasons. One is that some of the information of interest is not as easily available in the Scottish or Irish censuses, specifically the number of rooms occupied by a household. More important, for England and Wales we capture the effects of locality at the level of the registration district rather than at the county level. There were 635 registration districts in England and Wales with an average population of 51,200 in 1901 . The registration districts, which were based on poor law unions, encompass the diversity of local conditions much of which would be averaged away at the county level. We obtain key variables from the Decennial Supplement to the Registrar General's $65^{\text {th }}$ Annual Report. ${ }^{25}$ This contains demographic and other statistics for the decade 1891-1900, and these data are linked to the individual's location in the 1901 census.

For the purposes of analysis we have to drop some of the original matched cases. These are principally where height is missing, usually where the original document was burnt or water damaged. We also drop cases where the servicemen turned out not to be born in the 1890s and/or enlisted before 1910 or after 1922 . We also drop a few cases where the household

\footnotetext{
${ }^{24}$ There are three dimensions implicit in our measure of match quality. One is the extent of corroborative evidence, the most important of which is parent's name, address and birthplace. In some cases we have found the servicemen at the 'right' address and/or relatives in the 1911 census and then, with this additional information, traced the family back to 1901. Another is whether there is some element of inconsistency between the service record and the census summary, often errors of spelling in names and locations, especially in the attestation, or where first names are shortened (e.g. 'John' becomes 'Jack') or the order is reversed (e.g. 'Victor Edward' becomes 'Edward Victor'). A further issue is the (non)existence of other plausible alternatives. Cases where there is sufficient corroborative evidence and no conflicts are given grade of 4; cases where some anomaly such as in the names of relatives or birth places is far outweighed by other evidence are given a grade of 3 ; where there is limited corroborative evidence or more serious anomalies but we remain reasonably confident the grade is 2; and cases where there is some room for doubt, but the best option is chosen, are given 1 . Cases where there is simply insufficient information to discriminate between alternatives are not matched at all.

${ }^{25}$ See Registrar General, Decennial Supplement to the $65^{\text {th }}$ Annual Report; most of the data used here come from Part I, Table 1 pp. cxxx-clxiii and pp. 97-731.
} 
observed in the 1901 census contained more than 15 persons-usually lodging-houses or other institutions. This leaves us with a sample of 2236 cases, which we use in what follows.

\section{Army recruitment, the heights and background of soldiers}

By construction the men in our sample were relatively young and they enlisted relatively early. As shown in Table 1, the average date of attestation is halfway through 1915, with 20 percent enlisting after the introduction of conscription in March 1916. Age at the time of enlistment is measured in two ways, first from the attestation form and second by combining the date of attestation and the age recorded in the 1901 census. Although the means are relatively close the ages as measured by these alternative methods often differ and the correlation coefficient is only 0.83 . In part this is because age is recorded as whole years in the census and often on the attestation form. But in 12 percent of cases the age difference is more than two years. The average age of these individuals when observed in the 1901 census is 5.5 years and their average birth order is 3 .

As is well known, there was massive recruitment into the army during the Great War, with the total exceeding 5 million. It is estimated that 46.3 percent of males aged $15-49$ in England and Wales in 1911 were recruited into the army. Among those born in the 1890s it would have been about two thirds. ${ }^{26}$ For this reason alone those that enlisted would have been fairly representative of this cohort of men. Taking a sample from the original paper files Lamm concluded that the surviving records from W0363 (the burnt documents) were reasonably representative of non-commissioned ranks in the army as a whole and of the relevant population at large. ${ }^{27}$ One dimension of representativeness is the regional composition. Table 2 compares the proportions in registration divisions of children aged 0 to 9 in 1901 with those in our matched sample. Our sample is broadly representative although there are slightly more than expected from the regions of the south and east and somewhat fewer from the southwest and Wales. ${ }^{28}$

A common concern when analyzing height data from military recruits is the minimum height restriction. A number of different methods have been used to correct for truncation at the lower end of the height distribution. ${ }^{29}$ This is much less applicable to the First World War. Because of the continual pressure for military manpower recruitment standards declined as the War dragged on. In particular the height standard which was five feet three inches at the beginning of the war was progressively relaxed. ${ }^{30}$ This began in November 1914 with the

\footnotetext{
${ }^{26}$ Figure for all age groups from Winter, The Great War, p 28. The male population aged 15-24 in in 1911 was 3.2 million and the number who served (in all the forces) was approximately 2.1 million, op.cit, p. 82 .

${ }^{27}$ Lamm, 'British soldiers'.

${ }^{28}$ These deviations are somewhat similar to those found for all ages by Lamm 'British soldiers", p. 81-83

${ }^{29}$ See for example A'Hearn, 'A restricted maximum likelihood estimator', and Komlos, 'How to (and how not to)'.

${ }^{30}$ With the surge of volunteers in the first few months of the War the height standard was raised to $5^{\prime} 6^{\prime \prime}$ in September 1914 then lowered to 5' 4" in October and back to 5'3" in November. It was further reduced to 5' $2 "$ in May 1915. For the background to thes policies, see Grieves, The Politics of Manpower, Ch. 1, and Simkins Kitchener's Army, Ch. 4.
} 
first Bantam regiments for which the height range was between four feet ten inches and the normal standard of five feet three. ${ }^{31}$ The distribution of heights in our sample of servicemen is shown in Figure 1. The average height is five feet six inches and 9.5 percent are less than five feet three inches tall, while 10.8 percent are more than five feet nine. Although the mean is five feet six, for reasons that remain unclear, the modal value is five feet seven. The hypothesis that these heights follow a normal distribution can be rejected.

As Bodenhorn et al. have emphasized, there are many other sources of selection into the army that may lead to biased estimates of average height, especially for volunteer armies. ${ }^{32}$ Recruitment in the First World War was much less selective than it had been in the Boer War when more than a third of applicants were rejected as unfit for active service. ${ }^{33}$ Medical examinations were notoriously superficial and the rejection rate declined as the pressure for recruits mounted, and especially after the introduction of conscription. ${ }^{34}$ By the last year of the War (when a large proportion of those fit for service had already enlisted), only 10 percent of those examined were rejected as unfit for any kind of service. ${ }^{35}$ Only a very small proportion of these were rejected on the grounds of "poor physique", although the medical grounds for rejection could well have been correlated with height. ${ }^{36}$ Thus the army took men with a wide range of health statuses with only limited positive selection in terms of health and height. ${ }^{37}$ Indeed, many of those that had not enlisted by the end of the war were in reserved occupations and were not necessarily unfit for service.

Volunteers were healthier and fitter than conscripts. Army statistics indicate that among those recruited up to October 1917 almost all volunteers were classified as 'fit for general service' while only 64 percent of conscripts were so classified. ${ }^{38}$ If volunteers were indeed more positively selected then we should see a difference between the heights of those that enlisted before and after conscription, which came into force at the beginning of March 1916. ${ }^{39}$ During the period of conscription the proportion of volunteers was a small

\footnotetext{
${ }^{31}$ See Allinson, The Bantams. Bantam battalions accounted for about 50,000 recruits although many others below the height standard managed to enlist.

32 Bodenhorn et al., 'Problems of sample-selection bias'.

${ }^{33}$ Over the decade 1893 to 1902, 34.6 percent of those who underwent the army medical examination were rejected and a further 3 percent were discharged on medical grounds within two years, see Interdepartmental Committee on Physical Deterioration, 'Report', Appendix 1, pp. 95-97. As an unknown proportion of volunteers were rejected by recruiting officers without being subjected to medical inspection the total rejection rate would have been much higher, possibly more than half.

${ }^{34}$ Winter, The Great War, p. 52. He also describes the controversy arising from the inadequacy of medical examinations, noting that the doctors were paid only for those that they passed as fit, ibid, p. 50-3.

${ }^{35}$ Winter, The Great War, p. 57.

36 The Ministry of National Service, Report, provides a compilation of statistics from the examinations conducted by the National Service Medical Boards that were established in 1917.

${ }^{37}$ Following the medical examination they were assigned a letter grade, where ' $A$ " was 'fit for general service', B was 'fit for service abroad in a support capacity' and C was 'fit for home service only'.

${ }^{38}$ Army Council, General Annual Reports, p. 9.

${ }^{39}$ The Military Service Act of 1916 was passed in January and came into force on March $2^{\text {nd }} 1916$. It included all men aged 18 to 41 unless they were married or widowed with children. A further act of May 1916 that
} 
minority-only 12.5 percent. ${ }^{40}$ Just over 20 percent of our sample enlisted during the era of conscription and these were shorter than volunteers, on average by 0.3 of an inch (' $\mathrm{t}$ ' $=$ $2.2)^{41}$

We may conclude that conscription enhanced the representativeness of army recruits but there remain two important sources of selectivity in the records used here. While the surviving records in W0363 seem to be a random selection of the originals they do not include those enlisting in the navy which was generally regarded as a more elite service. More importantly, officers joining the army on commissions are also omitted. These were about five percent of the total army strength and they were drawn almost entirely from upper and middle class backgrounds. ${ }^{42}$ They are likely to have been fitter and taller than those from the lower classes. One estimate puts the mean height of officers at five feet nine inches. ${ }^{43}$ At the other end of the scale, W0363 does not include a selection of records that were transferred to the Ministry of Pensions. These evidently include a higher proportion of records of those who were discharged on medical grounds or as 'unlikely to become an efficient soldier". ${ }^{4}$

Returning to Table 1, we observe the mean family characteristics of the matched servicemen as children in 1901 . The average household consisted of 6.5 people with an average of 4.2 children in the family. On one hand we should expect to oversample relatively large families; on the other hand many of the families are incomplete when observed in the census. Of the 98 percent of households with a mother present her average age is 35.6. Of these, 19 percent were aged under 30 and 24 percent were over 40 . Nearly 6 percent of households were headed by females and in 7.6 percent the mother reported a gainful occupation. Not surprisingly, among female heads nearly half reported an occupation. The average number of earners in the household is 1.8 with over half having just one earner. Finally the occupation of the head of household was coded according to the Registrar General's 1921 social classification (rather than that of 1911) as suggested by Armstrong. ${ }^{45}$ Only 13.2 percent were in social classes 1 and 2 (professional and managerial) with a further 46.3 percent in class 3 (skilled).

The last part of Table 1 shows the average characteristics of the registration district in which the household was located in 1901. Households are observed in 473 out of the 635 registration districts. Not surprisingly these were typically the larger districts with an

extended conscription to married men is less relevant to our sample, only 8.3 percent of whom were married upon enlistment. Those attesting under the Derby scheme are counted as volunteers, as seems appropriate.

${ }^{40}$ This is for the period from $1^{\text {st }}$ March 1916 to $30^{\text {th }}$ June 1917 , after which volunteers were no longer separately distinguished-see Army Council, General Annual Reports, p. 60.

${ }^{41}$ Cranfield and Inwood, 'The great transformation', find similar results for Canadian servicemen.

${ }^{42}$ Simpson, 'The officers', p. 91.

${ }^{43}$ Pembury, 'Tall men versus short men,' p. 112 (comments by Sir Launcelot Gubbins).

${ }^{44}$ Lamm, 'British soldiers', p. 62.

${ }^{45}$ Armstrong, "The use of information," p. 205. 
average population of nearly 150,000 and with a density of nearly 21 persons per acre. ${ }^{46}$ The average individual in our sample was living in a district where 5.6 percent of households were overcrowded on the conventional measure of more than two persons per room. The Registrar General produced a rough classification of registration districts as heavily industrial or agricultural. ${ }^{47}$ These districts account for 27 percent and 14 percent respectively of those in our sample while the remainder came from mixed districts, provincial towns, and most importantly, London. The average rate of infant mortality in these districts from 1891 to 1900 was 152 per thousand-close to the average for England and Wales. Among those aged 0 to 9 the average mortality rate was much lower at 30 per thousand. In order to explore the effects of education we also construct a proxy for the district literacy rates of the parents' generation by taking the percentage of brides and grooms that signed the marriage register by mark in the years 1881 to $1884 .^{48}$ These show that, in the districts represented in our sample, more than 15 percent of women and 12 percent of men were illiterate at the time of marriage.

\section{Height and the household}

Here we explore how the heights of army recruits depend on the characteristics of the household in which they grew up, something that is rarely possible in historical data. The first column of Table 3 reports the results with only demographic variables included. We use age at enlistment as calculated from the date of attestation and age as reported in the census. As expected those aged less than 18 were significantly shorter, by more than half an inch, and those aged 18 and 19 by about quarter of an inch, than the omitted group, which is age 22 and above. These effects are relatively modest but they are consistent with the findings of others. In what follows we compare the results using the alternative age measure.

Birth order is naturally correlated with family size, as high birth orders are only observed in large families. In order to avoid conflating the separate effects of birth order and sibship size we use an adjusted measure of birth order: the difference between the individual's birth order and the sibship mean birth order. The result in column 1 suggests that, in contrast to some studies, there is no strong birth order effect on height as the coefficient is small and insignificant. It must be remembered, however, that birth order is calculated only for those present in 1901. More interesting is the effect of sibship size. The coefficient in column 1 indicates that height is inversely related to the number of children in the family. This reflects the trade-off between the quantity and the quality of children in the health dimension.

\footnotetext{
${ }^{46}$ At the 1901 census the average person lived in a registration district with a population of 139,539 and a density of 20.02 persons per acre.

${ }^{47}$ This classification was taken from the Registrar General, Decennial Supplement to the $65^{\text {th }}$ Annual Report, $\mathrm{p}$. viii.

481884 is the latest date for which this measure of literacy is reported by registration district. The mean age of first marriage for women in the 1880s was a little over 27 (Woods, The demography of Victorian England and Wales, p. 89).
} 
Across the range of family sizes from one to ten this would amount to a difference of more than an inch. ${ }^{49}$

It is important to recognize, however, that the families observed here are often incomplete and hence some of the children would have gained further siblings after 1901. We therefore include the age of the mother in 1901 to account for the probability of further siblings. The result is consistent with the notion that the older the mother, the smaller the expected addition to family size, and hence the positive effect on height. Mother's age is set to zero where there is no mother present and so a dummy is also included to account for families where there is no mother present and therefore no further siblings. ${ }^{50}$ As an alternative to adjusting for incomplete families with separate variables we create an adjusted sibship measure in which expected future births are added to the observed sibship size. This is based on a regression of sibship size on mother's age. ${ }^{51}$ The coefficient on predicted sibship size in column (2) gives a slightly larger coefficient with little change to the coefficients on other variables. Of course mother's age and no mother present could have direct effects on height, and when added to the column (2) regression, these were jointly significant (' $F$ ' = 3.19). A further hypothesis is that health and height depends on the sex composition of the sibship. If boys were given preference over girls then the share of girls in the sibship should have a positive effect on height. However, when added to the regression in column (2) the share of girls took a small and insignificant coefficient $(' t$ ' $=1.14) .{ }^{52}$

Further economic characteristics are added in column (3). The dummy for female headed households gives a negative coefficient and the effect of a working mother is positive but neither coefficient is significant. The ratio of earners (those with occupations) to total persons in the household gives a significant negative coefficient. It implies that in a six person household, going from two to three earners reduces height by quarter of an inch. Although more earners should mean more income per capita, the negative effect could be due to the marginalization of the needs of children relative to earners. It does not seem to be the result of crowding within the household, which is captured by a dummy for more

\footnotetext{
${ }^{49}$ However, this effect is considerably smaller than that estimated for children in poor families in the 1930 s, see Hatton and Martin, 'The effects on stature' p. 171.

${ }^{50}$ The effect of the dummy for no mother present is equivalent to having a mother aged 1.399/0.042 = 33.3.

${ }^{51}$ The regression coefficient for mothers aged 20 to 40 is $0.191(t=20.4)$. Thus for a mother aged 20 we add $(40-20) * 0.191=3.82$ children and for a mother aged 30 we add $(40-30) * 0.191=1.91$ children. For families where the mother is over 40 or there is no mother present, no further children are added. This gives an average predicted sibship size of 5.19 as compared with the unadjusted average of 4.16 . It is possible that in families with older mothers some siblings had left home but the decline in family size with age for mothers over 40 is very mild.

${ }^{52}$ Another issue is that, even though height is observed later than sibship size, endogeneity bias could arise from unobserved heterogeneity, giving rise to spurious correlation between height and sibship size. If mother's age and no mother present are used as instruments for predicted family size, the coefficient is -0.299 (' $t$ ' = 3.35). This is consistent with the finding of Hatton and Martin, 'The effects on stature' p. 172, in that instrumental variable estimation produces a negative coefficient which is larger in absolute size than ordinary least squares. One possible reason for a bias towards zero on the OLS estimate is that families with inherently poor heath have fewer surviving children.
} 
than one person per room and gives a significant negative coefficient. The effect of growing up in a crowded household is to reduce adult height by nearly a third of an inch. This is consistent with the arguments of contemporaries and subsequent observers who have stressed the negative effects of crowded and squalid conditions on children's health through the spread of infection. Although such inferences are often drawn from correlations across localities, here we observe the effect at the household level.

The social status of the family is represented by the occupational class of the household head. Here we include dummies for professional and managerial (class 1 or 2) and skilled occupations (class 3) in the Registrar General's 1921 classification. Servicemen who grew up in middle class families were taller than those from unskilled families by nearly half an inch. But the effect for skilled household heads is close to zero. Of course, social class is a poor proxy for income, but the result is a little surprising given the link between occupational class, health and mortality identified by the Registrar General in 1911 and by many others since. It suggests that some of the difference in height between classes and occupations works through family size and crowding within the household. As an alternative, in column (4), we use the CAMSIS occupational status score and find a weak positive effect for those occupations that could be coded. ${ }^{53}$

There are two sources of measurement error that could affect the results. These can be compared with a baseline regression in column (1) of Table 4, in which the least significant variables have been dropped. The first is the reporting of age. Although there is little difference in the mean age at enlistment as calculated from age in the 1901 census and that recorded on the attestation, it is possible that taller men systematically overstated their age (and vice versa). However there is only a weak correlation (0.04) between height and difference between the age recorded on the attestation and that calculated from age in the census and date of attestation. The regression in column (2) of Table 4 uses the attestation age rather than the census-based age. This gives coefficients for the younger age groups that are more negative and more significant, suggesting some systematic effect. However, the other coefficients are little affected by this change and so in what follows we continue to use age calculated from the census. The second possibility is that the army recruit has been matched to the wrong person in the census. This could account for the weaker age effects obtained when using census-based age rather than that recorded on the attestation. Accordingly column (3) drops the cases with lower match quality (1 or 2). The coefficients on the age variables change very little as compared with column (1) so the differences in the age effects between columns (2) and (3) do not seem to be due to false matches, and the coefficients on the household variables are little changed.

\footnotetext{
${ }^{53}$ The occupations were first coded using the HISCO coding scheme at: http://historyofwork.iisg.nl/index.php. These codes were then converted into the HISCAM index of social stratification using the universal scale at: http://www.camsis.stir.ac.uk/hiscam/.
} 
Finally, as noted above, the observed household effects could partially reflect differences across regions. Column (4) includes a full set of county dummies (coefficients not reported). The main differences are that no mother present and crowding lose significance while the effect of social class increases in size and significance. The $R^{2}$ also increases substantially suggesting that spatial differences matter, and we turn to this next.

\section{Height and the Locality}

We explore the effects of conditions in the locality as defined by the registration district. One question is the extent to which household effects are attenuated when locality characteristics are included. Another question is which locality effects are important and, if so, what they represent. Table 5 presents the results of adding locality variables to the baseline specification in column (1) of Table 4. Column (1) of Table 5 includes district population density, which although negative, is insignificant. It is possible that population density matters only beyond a certain threshold, but if this variable is replaced with a dummy for population density greater than 20 persons per acre, or 50 persons per acre, the coefficients (not shown) are similarly insignificant ( $\mathrm{t}$ ' $=0.55$ and ' $\mathrm{t}$ ' $=0.70$ respectively). Population density was evidently less important at the turn of the century that it was 50 years earlier. By contrast overcrowding, as conventionally measured, is rather more important, giving a negative and significant coefficient (column 2), which weakens the coefficient on crowding at the household level but has little effect on the other household coefficients.

Column (3) of Table 5 adds two dummies representing the Registrar General's broad classification of registration districts as 'industrial' or 'agricultural', the remainder being provincial towns and above all, London. Agricultural location has little effect on height, probably because markets were well integrated by this time. By contrast the industrial locations reduced height by nearly 0.9 of an inch, giving credence to the view that, even accounting for household conditions, industrial environments negatively affected growth in childhood. This somewhat reduces the coefficient on the share of earners in the household, which was higher in industrial districts, but it has little effect on the other coefficients.

The last column of Table 4 adds the district illiteracy rate of women who would have been of parental age in 1901. This is the percentage of women signing the marriage register by mark in the early 1880s. It has a significant negative effect, which implies that reducing the literacy rate by 10 percentage points would add quarter of an inch to height. The effect of mother's education has often been linked to the health of children at the individual level. Unfortunately we are only able to observe this at the district level, but it is possible that greater education and literacy in a locality helped to spread better methods of child nurturing. An alternative is that it could be a proxy for average income in the locality, but if so the effect would be better represented by male literacy. When the male illiteracy rate is added to the regression in column (4) it produced a positive coefficient (' $\mathrm{t}$ ' $=2.16$ ) while that on female illiteracy remains large and significantly negative. 
A more direct proxy for the disease environment is infant mortality. As noted above, variations in infant mortality are driven largely by gastro-intestinal and respiratory illnesses-infections that also inhibit the growth of children. As the first column of Table 6 shows, the average rate of infant mortality in the registration district in 1891-1900 has a strong negative effect on height. This suggests that the local disease environment had an important influence on health and height, and it implies that the scarring effect of infections dominated the selection effect. It is consistent with the findings of other studies, both in cross sections and over time. ${ }^{54}$ The difference between the first and third quartiles of infant mortality (4 percentage points) accounts for more than half an inch in height while the difference between the highest and lowest deciles accounts for nearly an inch.

A potential source of measurement error is where the family moved location sometime after the individual's birth but before the 1901 census. In that case the locality recorded at the census would only partially reflect the individual's early life environment. Because birthplaces are not consistently reported by registration district in the census we identify as movers only those who, in 1901, were not living in the county in which they were born. ${ }^{55}$ The regression in column (2) is for stayers only and, with the exception of social class, the coefficients differ only marginally from those in column (1). Most importantly the coefficient on infant mortality is little changed. On this basis we conclude that the results are not substantially influenced by measurement error.

The result in column (3) of Table 6 shows that when female illiteracy is added to the regression, the effect of infant mortality declines, suggesting that infant mortality reflects, in part, the knowledge and skills of mothers in the locality, as some contemporary observes suggested. ${ }^{56}$ Column (4) adds district overcrowding and the dummy for industrial districts, in the presence of which, the coefficient on infant mortality diminishes further and becomes insignificant. Consistent with other studies, the local disease environment, as reflected in infant mortality is linked to education, overcrowding and industry. ${ }^{57}$ Table 7 shows the relationship between infant mortality and these three variables across the 635 registration districts. Each has a strong positive effect and together they explain a good deal of the variation in infant mortality. Overall the results support the view that locality effects were important, that they work mainly through the disease environment, and that they are largely independent of the structure of the individual household.

\section{Conclusion}

\footnotetext{
${ }^{54}$ In a panel of town-level data for children aged 2-6 between 1920 and 1950 the equivalent coefficient converted to inches would be about - 0.1 (Hatton, 'Infant mortality', Table 3 p. 966).

${ }^{55}$ The regression of a dummy for movers on the individual's age in 1901 suggests that the probability of having moved away from the county of birth increases by 0.011 per year $(t=3.08)$.

${ }^{56}$ Newman, Infant mortality, p. 262-8; see also Fildes, 'Infant feeding practices'.

${ }^{57}$ Woods et al. 'The causes of rapid infant mortality decline', and Newell and Gazeley, 'The declines in infant mortality'.
} 
Census-linked data from the army service records provides insights into the socioeconomic circumstances affecting the height and health of individuals born in the $1890 \mathrm{~s}$. We find that the demographic structure of the household was important, especially the negative effect of number of children in the family. The degree of crowding in the household, the share of earners and social class also played a role. These channels of influence cannot be easily assessed using grouped data for regions and localities and their effects are robust to the inclusion of a range of variables representing the conditions in the locality. Yet in contrast to the results for more recent times locality effects are distinct and important. Our results suggest that the channel through which these local effects operated was principally via exposure to infection and disease. The three structural factors that influenced the disease environment were overcrowding, which captures the effects of slum dwellings, the industrial character of the district, and the degree of female illiteracy. This last effect is consistent with the findings for developing countries and it deserves further attention.

The results reported here have significant implications for understanding the dramatic improvement in health after 1890. In the following half century the height of males increased by about two inches. This was a period of rapid fertility decline, which reduced the average family size from around five children to two. This could have increased height by about a third of an inch. It also witnessed a decline in the rate of infant mortality from around 15 percent to just 6 percent, which would have added around one and a third inches. Improvements in the urban environment with the further advance of sanitary reform and housing renewal, and the gradual reduction of industrial pollution also contributed. Illiteracy virtually disappeared while average education increased by 2-3 years. More education combined with modest medical advances, brought better understanding of nutrition and hygiene. Together these developments help to explain the apparent puzzle of rapid improvement in average health status during a period of war and depression that predates the advent of universal health services. 


\section{References}

A'Hearn, B. (2003), "Anthropometric evidence on living standards in northern Italy, 17301860," Journal of Economic History, 63, pp. 351-381.

A'Hearn, B. (2004), "A restricted maximum likelihood estimator for truncated height samples," Economics and Human Biology 2, pp. 5-19.

Allinson, S. (2009), The bantams: The untold story of World War I, Barnsley, South Yorkshire: Pen and Sword Military.

Armstrong, W. A. (1972), "The use of information about occupation," in E. A. Wrigley (ed.), Nineteenth-century Society: Essays in the use of quantitative methods for the study of social data, Cambridge: Cambridge University Press.

Baten, J. (2009), "Protein supply and nutritional status in nineteenth century Bavaria, Prussia and France," Economics and Human Biology, 7, pp. 165-180.

Baten, J. and Murray, J. E. (2000), "Heights of men and women in $19^{\text {th }}$ century Bavaria: Economic, nutritional and disease Influences," Explorations in Economic History, 37, pp. 351369.

Bodenhorn, H., Guinnane, T. W. and Mroz, T. A. (2013), "Problems of sample-selection bias in the historical heights literature: A theoretical and econometric analysis," Yale Economics Working paper No. 114.

Bozzoli, C., Deaton, A. S. and Quintana-Domeque, C. (2009), 'Adult height and childhood disease" Demography, 76, pp.647-669.

Breschi, M., Fornasin, A., Manfredini, M., Mazzoni, S. and Pozzi, L. (2011), "Socioeconomic conditions, health and mortality from birth to adulthood, Alghero 1866-1925," Explorations in Economic History, 48, pp. 366-375

Burstrom, B., Diderichsen, F and Smedman, L. (1999), "Child mortality in Stockholm during 1885-1910: The Impact of household size and number of children in the family on risk of death from measles," American journal of Epidemiology, 149, pp. 1134-1141.

Cage, R. A. and Foster, J. (2002), "Overcrowding and infant mortality: A tale of two cities," Scottish Journal of Political Economy, 49, pp. 129-149.

Cavelaars, A. E. J. M., Kunst, A. E., Geurts, J. J. M., Crialesi, R., Grötvedt, L., Helmert, U., Lahelma, E., Lundberg, O., Mielk, A., Rasmussen, N. K., Regidor, E., Spuhler, T. and Mackenbach, J. P. (2000), "Persistent variations in average height between countries and between socio-economic groups: an overview of 10 European countries," Annals of Human Biology, 27, pp. 407-421. 
Cranfield, J. and Inwood, K. (2007), The great transformation: a long run perspective on physical well-being in Canada," Economics and Human Biology, 5, pp. 204-226.

Dewey, P. E. (1984), "Military recruiting and the British labour force during the First World War," Historical Journal, 27, pp. 199-223.

Fildes, V. (1998), "Infant feeding practices and infant mortality in England, 1900-1919," Continuity and Change, 13, pp. 251-280.

Grieves, K. (1988), The politics of manpower, 1914-1918, Manchester: Manchester University Press.

Haines, M. R., Craig, L.A. and Weiss, T. (2003), "The short and the dead: nutrition, mortality and the "antebellum puzzle" in the United States," Journal of Economic History, 63, pp. 382413.

Hatton, T. J. (2011), "Infant mortality and the health of survivors: Britain, 1910-1940," Economic History Review, 64, pp. 951-972.

Hatton, T. J. and Martin, R. M. (2010), "The effects on stature of poverty, family size and birth order: British children in the 1930s," Oxford Economic Papers, 62, pp. 157-184.

Horrell, S. and Oxley, D. (1999), "Crust or crumb? Intra-household resource allocation and male breadwinning in late Victorian Britain," Economic History Review, 52, 1999, pp. 494522.

Horrell, S. and Oxley, D. (2012), "Bringing home the bacon? Regional nutrition, stature and gender in the industrial revolution," Economic History Review, 65, pp. 1354-1379.

Humphries, J. (2007), “'Because they are too menny...' children, mothers, and fertility decline: The evidence from working-class autobiographies of the eighteenth and nineteenth centuries," in A. Janssens (ed.), Gendering the fertility decline in the western world, Bern: Peter Lang, pp. 113-150.

Humphries, J. and Leunig, T. (2009), "Cities, market integration, and going to sea: stunting and the standard of living in early nineteenth-century England and Wales," Economic History Review, 62, pp. 458-478.

Komlos, J. (2004), "How to (and how not to) analyze deficient height samples-an introduction," Historical Methods, 37, pp. 160-173.

Komlos, J. and Lauderdale, B.E. (2007), "Spatial correlates of US heights and body mass indexes 2002," Journal of Biosocial Science, 39, pp. 59-78. 
Konteh, F. H. (2009), "Urban sanitation and health in the developing world: reminiscing the nineteenth century industrial nations," Health and Place, 15, pp. 69-78.

Lamm, D. (1988), "British soldiers of the First World War: Creation of a representative sample," Historical Social Research/Historische Sozialforschung, 13, pp.55-98.

Lantzsch, J. and Schuster, K. (2009), "Socioeconomic status and physical stature in 19thcentury Bavaria," Economics and Human Biology, 7, pp. 46-54.

Martikainen, P., Kaupinnen, T. M. and Valkonen, T. (2003), "Effects of the characteristics of neighbourhoods and the characteristics of people on cause specific mortality: a register based follow up study of 252000 men," Journal of Epidemiology and Community Health, 57, pp. 210-217.

Newell, A. and Gazeley, I. (2012), "The declines in infant mortality and Fertility: Evidence from British cities in demographic transition," IZA Discussion Paper No. 6855

Newman, G. (1906), Infant mortality: A social problem, London: Methuen.

Orford, S., Dorling D., Mitchell, R., Shaw, M. and Davey Smith, D (2002), "Life and death of the people of London: a historical GIS of Charles Booth's inquiry," Health and Place, 8, pp. 25-35.

Pembury, M. S. (1915), "Tall men versus short men for the army," Journal of the Royal Sanitary Institute, 36, pp. 105-113.

Pickett, K.E and Pearl, M. (2001), "Multilevel analyses of neighbourhood socio-economic context and health outcomes: A critical review," Journal of Epidemiology and Community Health, 55, pp. 111-122.

Rowntree, B. S. (1901), Poverty: A study of town life, London: Macmillan.

Schneider, R. (1996), "Historical note on height and parental consumption decisions," Economics Letters, 50, pp. 279-283.

Silventoinen, K. Lahelma, E. Lundberg, O. and Rahkonen, O. (2001), "Body height, birth cohort and social background in Finland and Sweden," European Journal of Public Health, 11, pp. 124-129.

Simkins, P. (1988), Kitchener's army: The raising of the new armies, 1914-1916, London: Pen and Sword.

Simpson, K. (1985), "The officers," in I. F. W. Beckett and K. Simpson (eds.), A nation in arms: A social study of the British army in the First World War, Barnsley: Pen and Sword. 
Spencer, S. (2008), First World War army service records: A guide for family historians, Richmond, Surrey: National Archives.

Stafford, M. and Marmot, M. (2003), "Neighbourhood deprivation and health: does it affect us all equally?" International Journal of Epidemiology, 32, pp.357-366.

Steckel, R. H. (1995), "Stature and the standard of living," Journal of Economic Literature, 33, pp. 1903-1940.

Steckel, R. H. (2009), “Heights and human welfare: Recent developments and new directions," Explorations in Economic History, 46, pp. 1-23.

Szreter, S. and Mooney, G. (1998), "Urbanisation, mortality and the standard of living debate; new estimates of the expectation of life at birth in nineteenth-century British cities," Economic History Review, 50, pp.84-112.

Szreter, S. and Woolcock, M. (2004), "Health by association? Social capital, social theory, and the political economy of public health," International Journal of Epidemiology, 33, pp. 650-667.

Vynke, V., De Clercq, B., Stevens, V., Costongs, C.,Barbareschi, G., Jónsson, S. H., Corvo, S. D., Kebza, V., Currie, C. and Maes, L. (2013), “Does neighbourhood social capital aid in levelling the social gradient in the health and well-being of children and adolescents? A literature review," BMC Public Health, 13, Art 65.

Weir, D. R. (1993), "Parental consumption decisions and child health during the early French fertility decline, 1790-1914," Journal of Economic History, 53, pp. 259-274.

Williams, N. and Galley, C. (1995), "Urban-rural differentials in infant mortality in Victorian England," Population Studies, 49, pp. 401-420.

Winter, J. M. (2004), The Great War and the British people (2 ${ }^{\text {nd }}$ edn.), London: Palgrave Macmillan.

Woods, R. (2000), The demography of Victorian England and Wales, Cambridge: Cambridge University Press.

Woods, R. I., Watterson, P. A. and Woodward, J. H. (1989), "The causes of rapid infant mortality decline in England and Wales, 1861- 1921. Part II," Population Studies, Vol. 43, pp. 113-132.

\section{Official Documents}


Army Council (1921), General annual reports on the British army (Including the Territorial Force from the date of embodiment) for the period from $1^{\text {st }}$ October 1913 to $30^{\text {th }}$ September 1919, (Cmd. 1193), London: HMSO.

Inter-departmental Committee on Physical Deterioration, Report and Appendix (PP 1904 xxxii).

Ministry of National Service 1917-1919 (1920), Report, Vol. I, Upon the physical examination of men of military age by national service medical boards from November $1^{\text {st }} 1917-O c t o b e r$ $31^{\text {st }}, 1918$ (Cmd. 504), London: HMSO.

Newsholme, A., (1910) Report on infant and child mortality. Supplement to the $39^{\text {th }}$ annual report of the Local Government Board, London: HMSO.

Registrar General of England and Wales (1907), Supplement to the sixty-fifth annual report of the Registrar General of Births Deaths and Marriages in England and Wales, 1891-1900, (Cd. 2618), London HMSO.

Registrar General of England and Wales (1913), Seventy-fourth annual report of the Registrar General of Births Deaths and Marriages in England and Wales, 1911, (Cd. 6578), London: HMSO. 
Table 1: Descriptive statistics of servicemen-linked sample

\begin{tabular}{|l|r|r|}
\hline Individual Characteristics & \multicolumn{1}{|c|}{ Mean } & \multicolumn{1}{l|}{ S.D. } \\
\hline Height (inches) & 66.06 & 2.57 \\
\hline Attestation date (year) & 1915.5 & 1.36 \\
\hline Age recorded at attestation & 20.53 & 1.96 \\
\hline Age calculated from age in 1901 & 20.26 & 2.29 \\
\hline Birth order in 1901 & 3.04 & 1.88 \\
\hline Household characteristics & & \\
\hline Persons in household & 6.54 & 2.14 \\
\hline Sibship size & 4.16 & 2.08 \\
\hline Mother's age (if mother present) & 35.6 & 6.70 \\
\hline Female household head (\%) & 6.03 & 23.8 \\
\hline Mother an earner (\%) & 7.64 & 26.6 \\
\hline Earners per household & 1.81 & 1.15 \\
\hline Head social class 1 \& 2 (\%) & 13.2 & 33.8 \\
\hline Head social class 3 (\%) & 46.3 & 49.9 \\
\hline More than 1 person per room (\%) & 46.4 & 49.9 \\
\hline Locality characteristics & & \\
\hline Population (000s) 1901 & 148.6 & 126.9 \\
\hline Population density (persons per acre) 1901 & 20.8 & 36.7 \\
\hline More than 2 per room (\%) 1901 & 5.6 & 6.3 \\
\hline Infant mortality rate (\%) 1891-1900 & 15.2 & 2.9 \\
\hline Child mortality rate, 0-9 (\%) 1891-1900 & 3.0 & 0.9 \\
\hline 'Industrial' district (\%) & 27.0 & 44.4 \\
\hline 'Agricultural' district & 14.3 & 35.0 \\
\hline Female illiteracy (\%) 1881-4 & 15.3 & 9.2 \\
\hline Male Illiteracy (\%) 1881-4 & 12.6 & 6.6 \\
\hline
\end{tabular}

Table 2: Regional composition of population and servicemen, 1901

\begin{tabular}{|c|c|c|c|}
\hline \multicolumn{2}{|c|}{ Registration Division } & \multirow{2}{*}{$\begin{array}{l}1901 \\
\text { Census } \\
13.5\end{array}$} & \multirow{2}{*}{$\begin{array}{l}\text { Servicemen } \\
\text { Sample } \\
15.1\end{array}$} \\
\hline I & London & & \\
\hline II & South Eastern & 9.5 & 11.3 \\
\hline III & South Midland & 6.6 & 6.8 \\
\hline IV & Eastern & 5.9 & 7.6 \\
\hline V & South Western & 6.0 & 4.5 \\
\hline VI & West Midland & 11.5 & 10.6 \\
\hline VII & North Midland & 6.4 & 6.9 \\
\hline VIII & North Western & 16.0 & 14.5 \\
\hline IX & Yorkshire & 11.0 & 13.5 \\
\hline$x$ & Northern & 7.0 & 6.2 \\
\hline $\mathrm{X} 1$ & Wales & 6.4 & 3.1 \\
\hline
\end{tabular}


Table 3: Household Determinants of Height (in inches)

\begin{tabular}{|c|c|c|c|c|}
\hline & (1) & (2) & (3) & (4) \\
\hline Age $<18$ & $\begin{array}{r}-0.575 \\
(2.86)\end{array}$ & $\begin{array}{r}-0.729 \\
(2.41)\end{array}$ & $\begin{array}{r}-0.638 \\
(3.10)\end{array}$ & $\begin{array}{r}-0.657 \\
(3.18)\end{array}$ \\
\hline Age 18 & $\begin{array}{r}-0.250 \\
(1.47)\end{array}$ & $\begin{array}{r}-0.385 \\
(2.28)\end{array}$ & $\begin{array}{r}-0.338 \\
(1.97)\end{array}$ & $\begin{array}{r}-0.350 \\
(2.01) \\
\end{array}$ \\
\hline Age 19 & $\begin{array}{r}-0.297 \\
(1.64)\end{array}$ & $\begin{array}{r}-0.389 \\
(2.28)\end{array}$ & $\begin{array}{r}-0.374 \\
(2.08)\end{array}$ & $\begin{array}{r}-0.382 \\
(2.11)\end{array}$ \\
\hline Age 20 & $\begin{array}{r}-0.073 \\
(0.42)\end{array}$ & $\begin{array}{r}-0.070 \\
(1.39)\end{array}$ & $\begin{array}{r}-0.150 \\
(0.87)\end{array}$ & $\begin{array}{r}-0.140 \\
(0.81)\end{array}$ \\
\hline Age 21 & $\begin{array}{r}-0.018 \\
(0.09)\end{array}$ & $\begin{array}{r}-0.010 \\
(0.05)\end{array}$ & $\begin{array}{r}-0.039 \\
(0.20)\end{array}$ & $\begin{array}{r}-0.029 \\
(0.14)\end{array}$ \\
\hline Birth order index & $\begin{array}{r}-0.037 \\
(0.56)\end{array}$ & $\begin{array}{l}0.070 \\
(1.39)\end{array}$ & $\begin{array}{l}0.018 \\
(0.26)\end{array}$ & $\begin{array}{l}0.017 \\
(0.26)\end{array}$ \\
\hline Sibship size & $\begin{array}{r}-0.110 \\
(3.54)\end{array}$ & & $\begin{array}{r}-0.134 \\
(4.17) \\
\end{array}$ & $\begin{array}{r}-0.140 \\
(4.43)\end{array}$ \\
\hline Mother's age in 1901 & $\begin{array}{l}0.042 \\
(4.11) \\
\end{array}$ & & $\begin{array}{l}0.045 \\
(4.57) \\
\end{array}$ & $\begin{array}{l}0.048 \\
(4.72) \\
\end{array}$ \\
\hline No mother present & $\begin{array}{l}1.399 \\
(2.72)\end{array}$ & & $\begin{array}{c}1.608 \\
(3.13)\end{array}$ & $\begin{array}{l}1.742 \\
(3.33)\end{array}$ \\
\hline Predicted sibship size & & $\begin{array}{r}-0.139 \\
(4.58) \\
\end{array}$ & & \\
\hline Female head of household & $\begin{array}{r}-0.457 \\
(1.89)\end{array}$ & $\begin{array}{r}-0.447 \\
(1.83)\end{array}$ & $\begin{array}{r}-0.377 \\
(1.29)\end{array}$ & $\begin{array}{r}-0.328 \\
(1.09)\end{array}$ \\
\hline Mother an earner & & & $\begin{array}{r}-0.198 \\
(0.66)\end{array}$ & $\begin{array}{r}-0.158 \\
(0.52)\end{array}$ \\
\hline Earners/persons in household & & & $\begin{array}{r}-1.519 \\
(3.03)\end{array}$ & $\begin{array}{r}-1.659 \\
(3.33) \\
\end{array}$ \\
\hline More than 1 person per room & & & $\begin{array}{r}-0.278 \\
(2.39)\end{array}$ & $\begin{array}{r}-0.322 \\
(2.91) \\
\end{array}$ \\
\hline Head social class $1 \& 2$ & & & $\begin{array}{l}0.447 \\
(2.71)\end{array}$ & \\
\hline Head social class 3 & & & $\begin{array}{r}-0.060 \\
(0.50) \\
\end{array}$ & \\
\hline CAMSIS occupational status & & & & $\begin{array}{r}0.013 \\
(1.83) \\
\end{array}$ \\
\hline Occupation not classified & & & & $\begin{array}{l}0.770 \\
(1.77)\end{array}$ \\
\hline F-statistic & 5.38 & 6.08 & 6.18 & 5.69 \\
\hline R-squared & 0.022 & 0.021 & 0.038 & 0.036 \\
\hline No of observations & 2236 & 2236 & 2236 & 2235 \\
\hline
\end{tabular}

Note: $t$-statistics from robust standard errors clustered at the registration district level. 
Table 4: Household Effects--Alternative Specifications

\begin{tabular}{|l|r|r|r|r|}
\hline & \multicolumn{1}{|l|}{$\begin{array}{l}\text { (1) } \\
\text { Agseline } \\
\text { model }\end{array}$} & $\begin{array}{l}\text { Age from } \\
\text { attestation } \\
\text { form }\end{array}$ & $\begin{array}{l}\text { High match } \\
\text { quality }(>2)\end{array}$ & $\begin{array}{l}\text { County } \\
\text { dummies } \\
\text { included }\end{array}$ \\
\hline Age 18 & -0.575 & -1.051 & -0.575 & -0.697 \\
& $(3.57)$ & $(4.37)$ & $(3.57)$ & $(4.39)$ \\
\hline Age 19 & -0.259 & -0.667 & -0.255 & -0.272 \\
& $(1.80)$ & $(4.16)$ & $(1.57)$ & $(1.76)$ \\
\hline Sibship size & -0.308 & -0.403 & -0.308 & -0.320 \\
& $(2.03)$ & $(3.32)$ & $(1.91)$ & $(2.17)$ \\
\hline Mother's age in 1901 & -0.126 & -0.122 & -0.137 & -0.112 \\
& $(4.38)$ & $(4.22)$ & $(4.20)$ & $(3.90)$ \\
\hline No mother present & 0.047 & 0.044 & 0.047 & 0.036 \\
& $(5.23)$ & $(4.75)$ & $(4.64)$ & $(3.68)$ \\
\hline Earners/persons in household & 1.664 & 1.590 & 1.804 & 1.182 \\
& $(3.47)$ & $(3.27)$ & $(3.36)$ & $(2.23)$ \\
\hline More than 1 person per room & -1.656 & -1.682 & -1.690 & -1.063 \\
& $(3.91)$ & $(3.97)$ & $(3.46)$ & $(2.47)$ \\
\hline Head social class 1 \& 2 & -0.287 & -0.289 & -0.325 & -0.174 \\
& $(2.45)$ & $(2.48)$ & $(2.38)$ & $(1.51)$ \\
\hline F-statistic & 0.466 & 0.461 & 0.367 & 0.513 \\
\hline R-squared & $(2.93)$ & $(2.94)$ & $(2.11)$ & $(3.12)$ \\
\hline No of observations & 12.63 & 12.63 & 7.85 & 3.55 \\
\hline & 0.036 & 0.043 & 0.036 & 0.089 \\
\hline & 2236 & 2236 & 1831 & 2236 \\
\hline
\end{tabular}

Note: $t$-statistics from robust standard errors clustered at the registration district level, except col. (4). 
Table 5: Locality Determinants of Height (in inches)

\begin{tabular}{|c|c|c|c|c|}
\hline & $(1)$ & $(2)$ & (3) & (4) \\
\hline Age $<18$ & $\begin{array}{r}-0.571 \\
(3.54)\end{array}$ & $\begin{array}{r}-0.614 \\
(3.79)\end{array}$ & $\begin{array}{r}-0.677 \\
(4.25)\end{array}$ & $\begin{array}{r}-0.694 \\
(4.43)\end{array}$ \\
\hline Age 18 & $\begin{array}{r}-0.262 \\
(1.81)\end{array}$ & $\begin{array}{r}-0.273 \\
(1.90)\end{array}$ & $\begin{array}{r}-0.263 \\
(1.88)\end{array}$ & $\begin{array}{r}-0.283 \\
(2.03) \\
\end{array}$ \\
\hline Age 19 & $\begin{array}{r}-0.311 \\
(2.05)\end{array}$ & $\begin{array}{r}-0.310 \\
(2.02)\end{array}$ & $\begin{array}{r}-0.318 \\
(2.14)\end{array}$ & $\begin{array}{r}-0.339 \\
(2.29)\end{array}$ \\
\hline Sibship size & $\begin{array}{r}-0.126 \\
(4.38)\end{array}$ & $\begin{array}{r}-0.123 \\
(4.20)\end{array}$ & $\begin{array}{r}-0.115 \\
(3.88)\end{array}$ & $\begin{array}{r}-0.111 \\
(3.80)\end{array}$ \\
\hline Mother's age in 1901 & $\begin{array}{l}0.046 \\
(5.19)\end{array}$ & $\begin{array}{l}0.044 \\
(4.86)\end{array}$ & $\begin{array}{l}0.038 \\
(4.40)\end{array}$ & $\begin{array}{l}0.037 \\
(4.24) \\
\end{array}$ \\
\hline No mother present & $\begin{array}{c}1.648 \\
(3.44)\end{array}$ & $\begin{array}{l}1.561 \\
(3.24)\end{array}$ & $\begin{array}{l}1.332 \\
(2.83)\end{array}$ & $\begin{array}{l}1.267 \\
(2.72)\end{array}$ \\
\hline Earners/persons in household & $\begin{array}{r}-1.643 \\
(3.89) \\
\end{array}$ & $\begin{array}{r}-1.619 \\
(3.84) \\
\end{array}$ & $\begin{array}{r}-1.083 \\
(2.55)\end{array}$ & $\begin{array}{r}-1.035 \\
(2.48) \\
\end{array}$ \\
\hline More than 1 person per room & $\begin{array}{r}-0.271 \\
(2.26) \\
\end{array}$ & $\begin{array}{r}-0.191 \\
(1.60) \\
\end{array}$ & $\begin{array}{r}-0.169 \\
(1.43)\end{array}$ & $\begin{array}{r}-0.148 \\
(1.27) \\
\end{array}$ \\
\hline Head social class $1 \& 2$ & $\begin{array}{l}0.471 \\
(2.96) \\
\end{array}$ & $\begin{array}{c}0.491 \\
(3.13) \\
\end{array}$ & $\begin{array}{l}0.555 \\
(3.61) \\
\end{array}$ & $\begin{array}{l}0.533 \\
(3.48) \\
\end{array}$ \\
\hline $\begin{array}{l}\text { District population density, } 1901 \text { (100s } \\
\text { per acre) }\end{array}$ & $\begin{array}{r}-0.131 \\
(0.90) \\
\end{array}$ & $\begin{array}{l}0.195 \\
(1.01) \\
\end{array}$ & $\begin{array}{l}0.113 \\
(0.65) \\
\end{array}$ & $\begin{array}{r}-0.157 \\
(0.81) \\
\end{array}$ \\
\hline $\begin{array}{l}\text { District percent of households }>2 \\
\text { persons per room, } 1901\end{array}$ & & $\begin{array}{r}-0.036 \\
(2.82) \\
\end{array}$ & $\begin{array}{r}-0.037 \\
(3.13) \\
\end{array}$ & $\begin{array}{r}-0.020 \\
(1.46) \\
\end{array}$ \\
\hline District “Industrial” & & & $\begin{array}{r}-0.876 \\
(5.71)\end{array}$ & $\begin{array}{r}-0.632 \\
(3.88)\end{array}$ \\
\hline District "Agricultural" & & & $\begin{array}{r}-0.009 \\
(0.06) \\
\end{array}$ & $\begin{array}{r}-0.053 \\
(0.33) \\
\end{array}$ \\
\hline $\begin{array}{l}\text { District female illiteracy, percent of } \\
\text { marriages, 1881-4 }\end{array}$ & & & & $\begin{array}{r}-0.028 \\
(3.52)\end{array}$ \\
\hline F-statistic & 8.54 & 8.54 & 11.29 & 12.15 \\
\hline R-squared & 0.036 & 0.036 & 0.063 & 0.069 \\
\hline No of observations & 2236 & 2236 & 2236 & 2236 \\
\hline
\end{tabular}

Note: $t$-statistics from robust standard errors clustered at the district level. 
Table 6: Infant Mortality and Height (in inches)

\begin{tabular}{|c|c|c|c|c|}
\hline & $(1)$ & (2) & (3) & (4) \\
\hline Age $<18$ & $\begin{array}{r}-0.621 \\
(4.04)\end{array}$ & $\begin{array}{r}-0.599 \\
(3.63)\end{array}$ & $\begin{array}{r}-0.662 \\
(4.28)\end{array}$ & $\begin{array}{r}-0.686 \\
(4.42)\end{array}$ \\
\hline Age 18 & $\begin{array}{r}-0.289 \\
(2.03)\end{array}$ & $\begin{array}{r}-0.289 \\
(1.50)\end{array}$ & $\begin{array}{r}-0.299 \\
(2.12)\end{array}$ & $\begin{array}{r}-0.288 \\
(2.06)\end{array}$ \\
\hline Age 19 & $\begin{array}{r}-0.325 \\
(2.23)\end{array}$ & $\begin{array}{r}-0.297 \\
(1.83)\end{array}$ & $\begin{array}{r}-0.338 \\
(2.30)\end{array}$ & $\begin{array}{r}-0.336 \\
(2.29)\end{array}$ \\
\hline Sibship size & $\begin{array}{r}-0.110 \\
(3.88)\end{array}$ & $\begin{array}{r}-0.105 \\
(3.57)\end{array}$ & $\begin{array}{r}-0.106 \\
(3.79)\end{array}$ & $\begin{array}{r}-0.107 \\
(3.74)\end{array}$ \\
\hline Mother's age in 1901 & $\begin{array}{l}0.037 \\
(4.30)\end{array}$ & $\begin{array}{l}0.033 \\
(3.83)\end{array}$ & $\begin{array}{l}0.036 \\
(4.17)\end{array}$ & $\begin{array}{l}0.035 \\
(4.08)\end{array}$ \\
\hline No mother present & $\begin{array}{l}1.238 \\
(2.72)\end{array}$ & $\begin{array}{c}1.274 \\
(2.65)\end{array}$ & $\begin{array}{c}1.213 \\
(2.67)\end{array}$ & $\begin{array}{l}1.186 \\
(2.59)\end{array}$ \\
\hline Earners/persons in household & $\begin{array}{r}-1.141 \\
(2.79) \\
\end{array}$ & $\begin{array}{r}-0.957 \\
(2.27) \\
\end{array}$ & $\begin{array}{r}-1.104 \\
(2.71) \\
\end{array}$ & $\begin{array}{r}-0.974 \\
(2.36) \\
\end{array}$ \\
\hline More than 1 person per room & $\begin{array}{c}-0.195 \\
(1.65) \\
\end{array}$ & $\begin{array}{r}-0.215 \\
(1.74) \\
\end{array}$ & $\begin{array}{r}-0.177 \\
(1.53) \\
\end{array}$ & $\begin{array}{r}-0.153 \\
(1.31)\end{array}$ \\
\hline Head social class $1 \& 2$ & $\begin{array}{r}0.510 \\
(3.29) \\
\end{array}$ & $\begin{array}{l}0.378 \\
(2.07) \\
\end{array}$ & $\begin{array}{c}0.498 \\
(3.21) \\
\end{array}$ & $\begin{array}{l}0.534 \\
(3.48) \\
\end{array}$ \\
\hline District infant mortality rate (percent) & $\begin{array}{r}-0.146 \\
(7.40) \\
\end{array}$ & $\begin{array}{r}-0.147 \\
(6.99) \\
\end{array}$ & $\begin{array}{r}-0.104 \\
(4.30) \\
\end{array}$ & $\begin{array}{r}-0.065 \\
(2.25) \\
\end{array}$ \\
\hline $\begin{array}{l}\text { District female illiteracy, percent of } \\
\text { marriages, } 1881-4\end{array}$ & & & $\begin{array}{l}-0.025 \\
(3.33) \\
\end{array}$ & $\begin{array}{r}-0.019 \\
(2.41) \\
\end{array}$ \\
\hline $\begin{array}{l}\text { District percent of households }>2 \\
\text { persons per room, } 1901\end{array}$ & & & & $\begin{array}{r}-0.016 \\
(1.52)\end{array}$ \\
\hline District "Industrial" & & & & $\begin{array}{r}-0.466 \\
(2.57) \\
\end{array}$ \\
\hline F-statistic & 14.34 & 11.06 & 13.95 & 13.29 \\
\hline R-squared & 0.062 & 0.057 & 0.067 & 0.067 \\
\hline No of observations & 2236 & 1971 & 2236 & 2236 \\
\hline
\end{tabular}

Table 7: Determinants of Infant Mortality (District Level)

Infant mortality $=9.877+0.174$ Overcrowding +3.358 Industrial +0.123 Female illiteracy
(57.55) (10.07)
(10.30)
$(10.61)$

$\mathrm{R}^{2}=0.428, \mathrm{~N}=635,{ }^{\prime} \mathrm{t}$ ' statistics in parentheses. 
Figure 1: Distribution of heights in the matched sample of army recruits

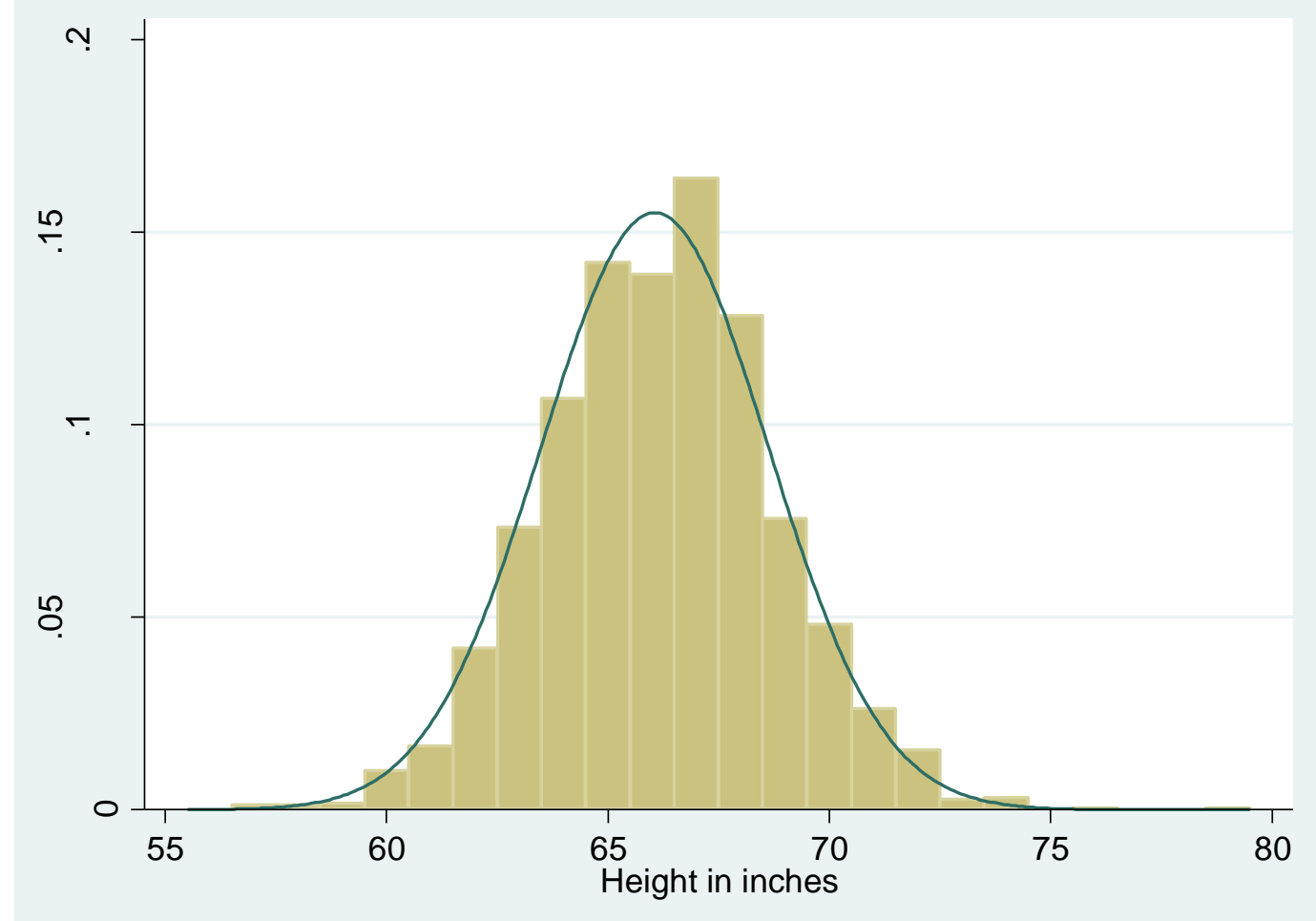

